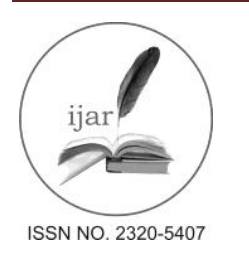

Journal homepage: http://www.journalijar.com
Journal DOI: 10.21474/IJAR01

INTERNATIONAL JOURNAL

OF ADVANCED RESEARCH

RESEARCH ARTICLE

\title{
STUDY OF 894 G>T SINGLE NUCLEOTIDE POLYMORPHISM OF ENDOTHELIAL NITRIC OXIDE SYNTHASE (ENOS) AND THE RISK OF DIABETIC NEPHROPATHY.
}

\author{
Dr. Parineeta Samant, Dr. Sandeepa Rai.
}

\section{Manuscript Info}

Manuscript History:

Received: 18 March 2016

Final Accepted: 22 April 2016

Published Online: May 2016

Key words:

Nitric oxide, Nitric oxide synthase, endothelial dysfunction, type 2 diabetes

*Corresponding Author

Dr. Parineeta Samant.

\begin{abstract}
Endothelial dysfunction plays is a major cause of pathogenesis of diabetic vascular disease, including diabetic nephropathy(DNP). A single nucleotide polymorphism in endothelial-derived nitric oxide synthase (eNOS) gene polymorphisms affect activity of eNOS and is associated with endothelial dysfunction.
\end{abstract}

Studies examining association of eNOS gene polymorphism in type 2 diabetic patients (T2DM) with diabetic nephropathy and without diabetic nephropathy are limited in Indian population. Thus, we investigated the genotype: phenotype association between potentially functional single nucleotide polymorphisms (SNPs) of the eNOSgene (894G>T) by PCRRFLP assays in diabetic subjects with and without nephropathy. We also measured serum Nitric Oxide (NO) levels in these subjects and examined its correlation with eNOS genotypes and diabetic nephropathy.

We observed that subjects carrying 'GT' genotype of $894 \mathrm{G}>\mathrm{T}$, were associated with increased risk of renal damage in type 2 diabetes.( $\mathrm{OR}=2.26$; $\mathrm{CI}=1.020-5.032)$ We also observed lower serum NO levels in T2DM subjects (both study and controls group) carrying GT+TT genotypes. Our study suggest that $894 \mathrm{G}>\mathrm{T}$ is associated with increased risk of nephropathy type 2 diabetic patients.

Copy Right, IJAR, 2016,. All rights reserved.

\section{Introduction:-}

Diabetic nephropathy (DN) is one of the most serious complications of diabetes with morbidity as high as $20-$ 40\%.(ADA 2002) DN is the leading cause of end-stage renal disease over the world and is the second cause of blood dialysis in China (13.5\%). Long-term exposure to a hyperglycemic environment, obesity, hypertension and hyperlipidemia contribute to the pathogenesis of DN. Many studies have suggested that DN is also influenced by genetic variants among metabolic-related genes (Borch-Johnsen et al., 1992; Doria et al., 1995, Quinn et al.,1996), it is widely accepted that individuals with diabetes may be at different levels of susceptibility to nephropathy. Many genes have been reported to be associated with DN, such as angiotensin-converting enzyme (ACE) (Hadjadj et al.,2007), endothelial nitric oxide synthases (eNOS), superoxide dismutase2 (Lee et al., 2006), among which eNOS has been emphasized a lot because endothelial dysfunction has been shown to be an important pathophysiologic denominator for DN.

NOS have three distinct isoforms according to their activity or the tissue type in which they were first described, including type 1 or neuronal NOS (nNOS), type 2 or inducible NOS (iNOS) and type 3 or endothelial NOS (eNOS), among which eNOS plays a key role in the regulation of vascular function including DN (Moncadaet al., 2006). The eNOS gene is located on chromosome7q35-36 and comprises 26 exons and 25 introns that span $21 \mathrm{~kb}$ and is expressed mainly in the endothelium.

Variants of the eNOS gene contribute to endothelial dysfunction and attenuate the NO Production (Ezzidi et al., 2008). The most clinically relevant polymorphisms that have been described in the eNOS gene is a $894 \mathrm{G}>\mathrm{T}$ 
substitution in exon 7, which is a single-nucleotide polymorphism (SNP) that results in a Glu- to- Asp substitution at codon 298 (Yoshimuraet al., 1998).

The study was undertaken to evaluate the risk of single nucleotide polymorphism,894 G>T of eNOS gene in T2DM patients with nephropathy. The phenotype association with serum nitric oxide and urine microalbumin was also studied.

\section{Material \&Methods:-}

This case-control study was started in February 2012 to December 2013. It included 120 type 2 diabetic patients (T2DM): 60 patients with nephropathy as cases and 60 without nephropathy as controls. They were recruited from diabetic OPD and Nephrology outpatient clinics of the MGM Hospital. All subjects were matched for age, gender and belonged to the same ethnic group. A written informed consent was obtained from all patients. The study was approved by our institute's ethics committee. Type 2 diabetes was defined as per ADA criteria 2012 (i.e., fasting glucose level > $126 \mathrm{mg} / \mathrm{dl}$ and/or 2-h postprandial glucose level > $200 \mathrm{mg} / \mathrm{dL}$ ) (ADA guidelines 2012). Patients who did not meet these criteria as under treatment but who gave a history of T2DM were also included in the study. Patients were divided into two groups:

1. Group I (Control): 60 patients without nephropathy who had T2DM for at least 5 years or more after diagnosis and whose albumin/creatinine ratio ACR was $<30 \mathrm{mg} / \mathrm{g}$ (Lamb et al., 2009). Diabetic subjects without proteinuria but on antihypertensive drug treatment were excluded from the study group.

2. Group II (Study group) : 60 patients with DN showed presence of proteinuria which was defined as albumin/creatinine ratio (ACR) in spot urine collection is $>300 \mathrm{mg} / \mathrm{g}$ (Lamb et al., 2009).

\section{Laboratory tests:-}

Serum NO was measured as nitrite/nitrate levels in subjects using Griess reagent (a 1:1 mixture of 1\% sulfanilamide in $5 \% \mathrm{H}_{3} \mathrm{PO}_{4}$ and $0.1 \% \mathrm{~N}$-1-napthyl-ethylenediamine)(Torre et al., 1996).

\section{Genetic analysis:-}

Genomic DNA was isolated from whole blood using the SIGMA-ALDRICH GenElute Blood Genomic DNA kit (Cat no NA2010).eNOS SNPs, namely, 894G > T (Glu298Asp; rs 1799983), was genotyped using the polymerase chain reaction-restriction fragment length polymorphism (PCR-RFLP). Primers for 894G > T SNP were the same as previously used primers by (Miyamoto et al., 1998). The location of SNPs in eNOS genes, reverse and forward primers, restriction enzyme used and annealing temperature along with product sizes, are presented in Table 1.

Table 1:- Standard Polymerase Chain Reaction Conditions Used in Genotyping 894G> T,Single-Nucleotide Polymorphisms of the eNOS Gene.

\begin{tabular}{|l|l|l|l|l|}
\hline SNP & Primers & $\begin{array}{l}\text { Amplicon } \\
\text { (bp) }\end{array}$ & $\begin{array}{l}\text { Annealing } \\
\text { temperature }\left({ }^{\circ} \mathrm{C}\right)\end{array}$ & $\begin{array}{l}\text { Restriction enzyme/ } \\
\text { allele size }\end{array}$ \\
\hline 894 & FP: 5' AAGGCAGGAGACAGTGGATGGA 3' & 261 & 62 & $\begin{array}{l}\text { Mbo I } \\
\text { (Thermoscietific; }\end{array}$ \\
G > T & RP: 5' CCCCTCCATCCCACCCAGTCAATC 3' & & & $\begin{array}{l}\text { \#ER0811) } \\
\text { G=158,103bp } \\
\text { T=261 }\end{array}$ \\
\hline
\end{tabular}

The PCR was done using Super PCR Mix kit (Thermo Fischer scientific) as following: 15 ml of Super PCR Mix was dispensed into each PCR vial, and then the following additions were done to each tube containing 10 $\mu$ (10ng) of extracted DNA, $1 \mu \mathrm{l}$ forward primer, and $1 \mu \mathrm{l}$ reverse primer (Eurofins) and then $03 \mu \mathrm{ldd} \mathrm{H}_{2} \mathrm{O}$ was added giving a final volume of $30 \mu \mathrm{l}$. The digested PCR products were resolved on $1.5 \%$ agarose gels stained with ethidium bromide for DNA integrity check.

\section{Statistical analysis:-}

The results for continuous variables are expressed as mean, standard deviation. The statistical significances of differences in frequencies of variants between the groups were tested using the chi-square $\left(\chi^{2}\right)$ test. In addition, the odds ratios (ORs) and 95\% confidence intervals (CIs) were calculated as a measure of the association of the eNOS alleles with groups. The Fisher Exact Probability test was performed to determine significance of the test. p-values 
were considered significant when $\mathrm{p}<0.05$. Bonferroni post hoc test is used for studying genotype:phenotype association.

\section{Results:-}

Demographic, clinical, and laboratory characteristics of the studied groups are shown in Table 2.

The genotype and allele frequencies of the eNOS polymorphisms in diabetic patients without nephropathy and diabetics with nephropathy are shown in Table 3. Genotype frequencies of all eNOS polymorphisms were in agreement with Hardy-Weinberg equilibrium in each study group For the 894G > T SNP, the TT genotype was significantly more frequent in diabetics with nephropathy than in diabetics without nephropathy $(25 \%$ vs. $15 \%$,); similarly, the T allele was more frequent in the DN group than in diabetics without nephropathy ( $\mathrm{p}<0.001$ ): OR and $95 \%(\mathrm{CI})$ for the $\mathrm{T}$ allele of $894 \mathrm{G}>\mathrm{T}=2.26(1.020-5.032)$.

Table 2:- Descriptive statistics of biochemical analysis in Control and Study Group.

\begin{tabular}{|l|l|l|l|}
\hline Test parameters & $\begin{array}{l}\text { Group I } \\
\text { n=60 } \\
\text { (Diabetic without } \\
\text { Nephropathy) }\end{array}$ & $\begin{array}{l}\text { Group II } \\
\text { n=60 } \\
\text { Diabetic with } \\
\text { Nephropathy }\end{array}$ & P Value \\
\hline Known diabetes duration (years) & $5-7$ yrs & $5-8$ yrs & - \\
\hline Age $($ years) & $55 \pm 8.1$ & $58 \pm 8.8$ & 0.069 \\
\hline BMI $(\mathrm{kg} / \mathrm{m} 2)$ & $28.7 \pm 4.52$ & $28.4 \pm 4.98$ & 0.73 \\
\hline Systolic blood pressure $(\mathrm{mmHg})$ & $136.9 \pm 11.77$ & $145 \pm 11.99$ & $0.0001^{*}$ \\
\hline Diastolic blood pressure $(\mathrm{mmHg})$ & $99.82 \pm 11.66$ & $109 \pm 13$ & $0.0001^{*}$ \\
\hline FBS $(\mathrm{mg} / \mathrm{dl})$ & $207 \pm 59.3$ & $276 \pm 108$ & $0.0001^{*}$ \\
\hline Hb A1 c $(\%)$ & $7.52 \pm 1.28$ & $7.9 \pm 1.9$ & 0.20 \\
\hline Total cholesterol $(\mathrm{mg} / \mathrm{dl})$ & $205 \pm 33.3$ & $220 \pm 59$ & 0.08 \\
\hline HDL cholesterol $(\mathrm{mg} / \mathrm{dl})$ & $38 \pm 5.5$ & $37 \pm 5.5$ & 0.31 \\
\hline LDL cholesterol $(\mathrm{mg} / \mathrm{dl})$ & $128 \pm 34$ & $136 \pm 53.6$ & 0.33 \\
\hline VLDL cholesterol $(\mathrm{mg} / \mathrm{dl})$ & $46 \pm 32$ & $49 \pm 17$ & 0.53 \\
\hline Triglycerides & $216 \pm 73$ & $228 \pm 79$ & 0.39 \\
\hline Creatinine $(\mathrm{mg} / \mathrm{dl})$ & $1.7 \pm 0.9$ & $6.57 \pm 2.7$ & $0.0001^{*}$ \\
\hline Albumin/creatinine $\mathrm{ratio} \mathrm{mg} / \mathrm{g}$ & $25 \pm 7.8$ & $467 \pm 22.213$ & $0.0001^{*}$ \\
\hline Microalbumin $(\mathrm{mg} / \mathrm{dl})$ & $61.09 \pm 27.56$ & $139 \pm 88.7$ & $0.0001^{*}$ \\
\hline Niric oxide $(\mu \mathrm{mol} / \mathrm{l})$ & $0.16 \pm 0.05$ & $0.14 \pm 0.04$ & $0.01^{*}$ \\
\hline
\end{tabular}

Data are reported as mean $\pm \mathrm{SD}$, median (range), or percentage. P-values were obtained by the unpaired Student's $\mathrm{t}$

Table 3:- Genotype and allelic frequency in Control and Study group.

\begin{tabular}{|l|l|l|l|l|l|}
\hline Groups & GG & GT & TT & G allele & T allele \\
\hline Group I (Type 2 diabetes ;N=60) & $34(57 \%)$ & $17(28 \%)$ & $09(15 \%)$ & $71 \%$ & $29 \%$ \\
\hline $\begin{array}{l}\text { Group II } \\
\text { Type 2 diabetes with nephropathy; } \\
\text { N=60) }\end{array}$ & $22(37 \%)$ & $23(38 \%)$ & $15(25 \%)$ & $56 \%$ & $44 \%$ \\
\hline
\end{tabular}

Table 4:- Association of eNOS gene polymorphism with disease.

\begin{tabular}{|l|l|l|l|l|l|l|}
\hline Groups & Genotypes & \multirow{2}{*}{$\chi^{2}$ Test } & \multicolumn{2}{|l|}{ Fischer Exact Test } \\
\cline { 2 - 7 } & GG & GT & TT & & $\begin{array}{l}\text { Odds Ratio } \\
\text { 95\% CI }\end{array}$ & P value \\
\hline $\begin{array}{l}\text { T2DM (Control group } \\
\text { N=50) }\end{array}$ & $57 \%$ & $28 \%$ & $15 \%$ & - & - & - \\
\hline $\begin{array}{l}\text { Type 2 diabetes with } \\
\begin{array}{l}\text { Nephropathy } \\
\text { Group (N=60) }\end{array}\end{array}$ & $37 \%$ & $38 \%$ & $25 \%$ & 4.821 & $2.26(1.020-5.032)$ & 0.029 \\
\hline
\end{tabular}


Table 5:- Genotype Association study.

\begin{tabular}{|l|l|l|l|l|l|}
\hline Parameters & Genotype & Group I & $\begin{array}{l}\text { Within Group } \\
\text { Pairwise } \\
\text { comparison } \\
\text { GG Vs GT+TT }\end{array}$ & Group II & $\begin{array}{l}\text { Within } \\
\text { pairwise } \\
\text { comparison } \\
\text { GG Vs GT+TT }\end{array}$ \\
\hline $\begin{array}{l}\text { Serum Nitric } \\
\text { oxide } \\
(\mu \mathrm{mol} / \mathrm{l})\end{array}$ & $\mathrm{G} / \mathrm{G}$ & $0.16 \pm 0.05$ & \multirow{2}{*}{0.22} & $0.13 \pm 0.03$ & \multirow{2}{*}{0.001} \\
\cline { 2 - 5 } $\begin{array}{l}\text { Urinary } \\
\text { Microalbumin } \\
(\mathrm{mg} / \mathrm{dl})\end{array}$ & $\mathrm{G} / \mathrm{T}+\mathrm{T} / \mathrm{T}$ & $0.15 \pm 0.04$ & $0.09 \pm 0.02$ & $136.6 \pm 65.1$ & \multirow{2}{*}{0.03} \\
\cline { 2 - 3 } & G/G & $58.3 \pm 29.7$ & \multirow{2}{*}{0.18} & $156.4 \pm 104.2$ & \\
\hline
\end{tabular}

Genotype specific Mean \pm SD for each group

\section{Discussion:-}

Endothelial dysfunction has been commonly found in patients with type 2 diabetes and diabetes with nephropathy, and is considered the central pathophysiologic factor for all cardiovascular and renal complications of type 2 diabetes.

Nitric oxide (NO) plays fundamental role in the regulation of endothelial function and vascular tone in many organs including kidney. It also inhibits platelet aggregation, leukocyte adhesion to vascular endothelium \& oxidation of LDL (Suryanarayana et al.,2006)NO is produced by NOS enzyme which exhibits three isoforms: neuronal (nNOS), inducible (iNOS) and endothelial (eNOS). Endothelium-derived NO is synthesized from L-arginine by NO synthase coded by eNOS (eNOS or NOS3) gene, mapped on chromosome 7q36. Upon release, NO diffuses rapidly through the cell membrane and relaxes neighboring vascular smooth cells through the production of guanine 3'5'-cyclic monophosphate (cGMP). Impairment of NO production causes endothelial dysfunction contributing to the development of insulin resistance, type 2 diabetes, chronic renal failure and cardiovascular complications including hypertension and hypercholesterolemia.(Shinet al., 2010) Due to the importance of eNOS in the generation of NO that regulates endothelial-dependent vasodilation in many organs, we made an attempt to evaluate the role of 894 $\mathrm{G}>\mathrm{T}$ eNOS gene polymorphisms in the eNOS gene and NO availability in type 2 diabetes and diabetes with nephropathy.

In our study, the frequency of the GG, GT and TT genotypes of eNOS gene in Group I (T2DM) was found to be $57 \%, 28 \%$ and $15 \%$ respectively. It was $37 \%, 38 \%$ and $25 \%$ respectively, in Group II (T2DM with nephropathy). The frequency of $\mathrm{G}$ and $\mathrm{T}$ allele was found to be $71 \%, 29 \%$ in Group I, 56\%, 44\% resp. in Group II as presented in table 3.

Thus the findings of the study revealed that the TT genotype and the T allele of eNOS 894G>T polymorphism were significantly more frequent in diabetics with nephropathy than in diabetics without nephropathy. Our results were supported by (Ahluwalia et al.,2008)in a cohort of T2DMpatients of Mixed North Indian ethnicity. Also, (Nagaseet al., 2003) found a higher prevalence of 894T in Japanese patients with diabetes mellitus as a cause of renal failure, and added that this polymorphism has been proposed as a candidate factor for the accelerated nephropathy in type 2 diabetes mellitus. Ezzidi et al., (2008) found increased TT genotype in DN compared to diabetics without nephropathy in Tunisian patients.

We employed Fischer's exact test and 2x2 contigency table (for odds ratio) as the most suitable statistical tool for genetic analysis. GT+TT genotypes were combined for genotype: phenotype analysis due to low frequency of TT in our population.

The frequency of GG and (GT+TT) genotype of Group I (T2DM) and Group II (T2DM with nephropathy) when compared by Chi -square analysis showed an odds ratio of 4.82 for type 2 diabetes with nephropathy as shown in table 4,supporting the finding that diabetic patient showing presence of G894T polymorphism have increased risk of nephropathy.

The Glu298Asp missense mutation encoded by exon 7 of the eNOS gene is a common variant of eNOSthat has a guanine $(\mathrm{G})$ to thymine $(\mathrm{T})$ transversion at nucleotide position 894 , resulting in a replacement of glutamic acid by 
aspartic acid at codon 298 (Glu298Asp). 894G>Tis associated with reduced basal NO production and has been reported to be associated with an increased risk for hypertension renal damage, myocardial infarction, coronary artery spasm, hypertension etc.(Senthil et al., 2005, Hyndman et al.,2002, Karvela et al.,2008, Makino et al., 2004).

The Glu298Asp polymorphism causes a structural change of the eNOS protein and reduces eNOS activity and ultimately nitric oxide production. Therefore, the gene coding for eNOS can be a good candidate gene for evaluating risk of occurrence of diseases in type 2 diabetes with and without renal complications and its association with endothelial markers like NO and urinary microalbumin.

When the serum nitric oxide levels of both the GG and (GT+TT) genotypes of type 2 diabetes patients were compared, no significant difference was found but comparison of serum nitric oxide of GG genotype vs GT +TT genotype of type 2 diabetes with nephropathy showed significant difference. Complications in diabetes are due to microangiopathies attributed to endothelial damage which in turn affects the production of the protective NO.

Urinary microalbumin, the second endothelial marker of GG and (GT +TT) genotypes subjects in study group as well as in control showed statistical significance.

Urinary microalbumin of GG genotype subjects of group I when compared with those of (GT +TT) genotype of same, statistically insignificant relationship was observed but comparison of GG genotype with that of (GT+ TT) genotype of Group II has shown significant difference. Thus it can be stated that variance of G894T has association with urinary microalbumin in renal conditions.

In conclusion, the effect of eNOS gene G894T SNP is observed in T2DM with nephropathy in terms of changes in phenotypic variables such as HOMA IR and Serum nitric oxide and urinary microalbumin. The genotype variants seem to influence the endothelial damage as seen by the changes in NO levels. Genetic research in the field of diabetic nephropathy has two key goals. In the longer term such research can make a major contribution to understanding the pathophysiology of the condition and aid the development of new therapeutic strategies. The more immediate goal is to improve on currently available screening strategies such as testing for microalbuminuria. If the genetic susceptibility factors are determined, people could be screened at diagnosis of diabetes so that available preventative measures (e.g. inhibition of the renin-angiotensin system and blood pressure reduction) could be most effectively and consistently targeted.

\section{Limitations:-}

The study population included patients visiting diabetic OPD of our tertiary care hospital. The role of genes in diabetic nephropathy should be sought from much larger sample size.

\section{Acknowledgement:-}

This work was supported by MGM Medical College and Hospital, Kamothe, Navi-Mumbai, India.

\section{Competing Interests:-}

The authors have no competing interests.

\section{References:-}

1. Al-Katanani, Y.M., Paula Lopes, F.F. and Hansen, P.J. (2002).Effect of season and exposure to heat stress on oocyte quality of Holstein cows. J. Daiy Sci. 58: 171-182.

2. ADA. Diabetic nephropathy( 2002). Diabetes Care, 25 (1), S85-S89.

3. Borch-Johnsen, K., Norgaard, K., Hommel, E., Mathiesen, E. R., Jensen, J. S., Deckert, T. and Parving, H. H. (1992). Is diabetic nephropathy an inherited complication? Kidney Int. 41:719-722.

4. Doria, A., Warram, J. H. and Krolewski, A. S. (1995). Genetic susceptibility to nephropathy in insulindependent diabetes: from epidemiology to molecular genetics. Diabetes Metab.Rev. 11: 287-314.

5. Quinn, M., Angelico, M. C., Warram, J. H. and Krolewski, A. S. (1996). Familial factors determine the development of diabetic nephropathy in patients with IDDM. Diabetologia. 39: 940-945.

6. Hadjadj, S., Tarnow, L., Forsblom, C. et al. (2007). Association between angiotensin-converting enzyme gene polymorphisms and diabetic nephropathy: case-control, haplotype, and family-based study in three European populations. J. Am. Soc. Nephrol. 18:1284-1291. 
7. Lee, S. J., Choi, M. G., Kim, D. S. and Kim, T. W. (2006). Manganese superoxide dismutase gene polymorphism (V16A) is associated with stages of albuminuria in Korean type 2 diabetic patients. Metabolism. 55:1-7.

8. Moncada, S. and Higgs, E. A. (2006). The discovery of nitric oxide and its role in vascular biology. Br. J. Pharmacol.147 (1): S193-S201.

9. Ezzidi I, Mtiraoui N, Mohamed MB, et al. (2008). Association of endothelial nitric oxide synthase Glu298Asp, 4b/a, and - 786T >C gene variants with DN. J Diabetes Complications.

10. 22:331-338.

11. Yoshimura M, Yasue H, Nakayama M, et al. (1998). A missense Glu298Asp variant in the endothelial nitric oxide synthase gene is associated with coronary spasm in the Japanese. Hum

12. Genet 103:65-69.

13. Standards of Medical Care in Diabetesd (2012).Diabetes Car. 35(1): S11-63

14. Lamb EJ, MacKenzie F, Stevens PE. (2009). How should proteinuria be detected and measured? Ann ClinBiochem. 46:205-217.

15. Torre D, Ferrario G, Matteelli A, et al. (1996). Levels of circulating nitrate/nitrite and gamma interferon not increased in uncomplicated malaria. Infection. 26:301-303.

16. Miyamoto Y, Saito Y, Kajiyama N, et al. (1998). Endothelial nitric oxide synthase gene is positively associated with essential hypertension. Hypertension. 32:3-8

17. Suryanarayana V, Rao L, Kanakavalli M, Padmalatha V, Deenadayal M, Singh L(2006). Recurrent early pregnancy loss and endothelial nitric oxide synthase gene polymorphisms. Arch Gynecol Obstet.274(2):119124.

18. Shin SJ, Lee HH, Cha SH, Kim JH, Shim SH, Choi DH, Kim NK.(2010). Endothelial nitric oxide synthase gene polymorphisms $(-786 \mathrm{~T}>\mathrm{C}, 4 \mathrm{a} 4 \mathrm{~b}, 894 \mathrm{G}>\mathrm{T})$ and haplotypes in Korean patients with recurrent spontaneous abortion. European journal of Obstetrics and Gynceology and Reproductive Biology.152(1): 64-67.

19. Ahluwalia TS, Ahuja M, Rai TS, et al. (2008).Endothelial nitric oxide synthase gene haplotypes and DN among Asian Indians. Mol Cell Biochem. 314:9-17.

20. Nagase S, Suzuki H, Wang Y, et al. (2003). Association of ecNOS gene polymorphisms with end stage renal diseases.Mol Cell Biochem. 244:113-118.

21. Senthil D, Raveendran M, Shen YH, Utama B, Dudley D, Wang J, Wang XL.(2005). Genotype dependent expression of endothelial nitric oxide synthase (eNOS) and its regulatory proteins in cultured endothelial cells. DNA Cell Biology.24(4):218-224.

22. Hyndman ME, Parsons HG, Verma S, Bridge PJ, Edworthy S, Jones C, Lonn E, Charbonneau F, Anderson TJ. (2002). The T-786 $\rightarrow$ C Mutation in Endothelial nitric oxide synthase is associated with hypertension. Hypertension.39(4): 919-922.

23. Karvela M, Papadopoulou S, Tsaliki E, Konstantakou E, Hatzaki A, Florentin-Arar L, Lamnissou K: (2008). Endothelial nitric oxide synthase gene polymorphisms in recurrent spontaneous abortions. Archives of Gynecology and Obstetrics.2008;278(4): 349-352.

24. Makino A, Nakanishi T, Sugiura-Ogasawara M, Ozaki Y, Suzumori N, Suzumori K. (2004). No association of C677T methylenetetrahydrofolatereductase and an endothelial nitric oxide synthase polymorphism with recurrent pregnancy loss. American Journal of Reproductive Immunology.2(1):60-66. 